\title{
EWOLUCJA GLOBALNEJ NIERÓWNOWAGI PŁATNICZEJ W POKRYZYSOWEJ GOSPODARCE ŚWIATOWEJ
}

Globalna nierównowaga płatnicza, której istotą jest występowanie chronicznych deficytów i nadwyżek bilansu obrotów bieżących krajów istotnych systemowo, stanowi jeden z kluczowych problemów współczesnej gospodarki światowej. Zjawisko to podlegało jednak znacznej ewolucji po globalnym kryzysie finansowym.

Przedstawienie tej ewolucji jest celem artykułu. Teza opiera się na stwierdzeniu, że globalna nierównowaga płatnicza pozostaje trwałą cechą pokryzysowej gospodarki światowej, przy czym znaczącej ewolucji uległa grupa krajów nadwyżkowych, w odniesieniu do której największe znaczenie ma przywrócenie równowagi zewnętrznej w Chinach, podczas gdy grupa krajów deficytowych pozostała prawie niezmieniona, z umocnioną rolą Stanów Zjednoczonych i Wielkiej Brytanii. Zastosowane metody badawcze obejmują analizę danych statystycznych dotyczących bilansu obrotów bieżących oraz międzynarodowej pozycji inwestycyjnej krajów członkowskich Międzynarodowego Funduszu Walutowego (MFW), a także analizę porównawczą i studium literatury przedmiotu.

\section{Istota i metody kwantyfikacji globalnej nierównowagi płatniczej}

Kładąc nacisk na trwałość nierównowag zewnętrznych poszczególnych krajów, K. Lutkowski definiuje globalną nierównowage płatniczą jako stan, w którym permanentnym nadwyżkom w bilansach obrotów bieżących jednej grupy krajów odpowiadają równie chroniczne deficyty obrotów bieżących innej grupy krajów Globalna nierównowaga płatnicza jest rezultatem zaburzeń w gospodarkach poszczególnych krajów, a także prowadzonej przez nie polityki gospodarczej. Nierównowagi zewnętrzne tych krajów są pochodnymi ich nierównowagi wewnętrznej. Ze względu na to globalną nierównowagę płatniczą definiuje się jako sytuację, w której nierównowagi zewnętrzne krajów istotnych systemowo (systemically important

ORCID: 0000-0001-5751-9282, DOI: 10.4467/23538724GS.20.022.12140

1 K. Lutkowski, Globalna nierównowaga platnicza i obecny krysys finansony, „Zeszyty Naukowe Kolegium Gospodarki Światowej SGH” 2011, nr 29, s. 7. 
economies) odzwierciedlają zaburzenia w ich gospodarkach oraz stwarzają ryzyko dla gospodarki światowej ${ }^{2}$. Nierównowaga zewnętrzna odnosi się tu przede wszystkim do nierównowagi bilansu obrotów bieżących, a także międzynarodowej pozycji inwestycyjnej. Gospodarki istotne systemowo to natomiast takie, których kondycja ze względu na ich wielkość oraz powiązanie z gospodarka światowa - ma istotny wpływ na gospodarki innych krajów oraz cała gospodarkę światową. Określenie „zaburzenia” (distortions) w gospodarkach krajów przyczyniających się do powstania i utrzymywania się globalnej nierównowagi odnosi się z kolei do realizowanej przez nie polityki gospodarczej, problemów strukturalnych i związanej z nimi nierównowagi wewnętrznej tych państw ${ }^{3}$.

Globalna nierównowaga płatnicza to zjawisko kwantyfikowalne. Opisuje ją wiele miar, z których najważniejszą jest stosunek sumy bezwzględnych wartości sald bilansów obrotów bieżących poszczególnych krajów do światowego PKB. Określony w ten sposób wskaźnik globalnej nierównowagi ukazuje, jak duże są rozmiary nierównowag w bilansach obrotów bieżących w stosunku do globalnego PKB w danym roku. Oblicza się go w następujący sposób ${ }^{4}$ :

$$
\mathrm{GI}=\frac{\sum_{i=1}^{n}\left|\mathrm{CAB}_{i}\right|}{\mathrm{GDP}_{w}}
$$

gdzie:

GI - wskaźnik globalnej nierównowagi płatniczej,

$\mathrm{CAB}_{i}$ - wartość salda bilansu obrotów bieżących kraju $i$,

$\mathrm{GDP}_{w}$ - wartość światowego PKB.

Wskaźnik globalnej nierównowagi, choć informuje o jej wielkości, nie ukazuje jednak udziału poszczególnych krajów w jej tworzeniu. W związku z tym pomocna jest także inna miara, mianowicie stosunek bezwzględnej wartości salda bilansu obrotów bieżących danego kraju do sumy bezwzględnych wartości sald bilansu obrotów bieżących wszystkich krajów5. Wskaźnik ten oblicza się za pomocą następującego wzoru:

2 T. Bracke, M. Bussiere, M. Fidora, R. Straub, A Framework, for Assessing Global Imbalances, Occasional Paper No. 78, European Central Bank, Frankfurt am Main 2008, s. 12.

3 O. Blanchard, G. Milesi-Ferretti, Global Imbalances: In Midstream?, Staff Position Note No. SPN/09/29, International Monetary Fund, Washington, DC 2009, s. 4.

4 Rebalancing the Global Economy: A Primer for Policymaking, eds. S. Claessens, S. Evenett, B. Hoekman, London 2010, s. 11.

5 T. Bracke, M. Bussiere, M. Fidora, R. Straub, A Framework..., s. 18. 


$$
\mathrm{GI}_{i}=\frac{\left|\mathrm{CAB}_{i}\right|}{\sum_{i=1}^{n}\left|\mathrm{CAB}_{i}\right|}
$$

gdzie:

$\mathrm{GI}_{i}-$ udział kraju $i$ w tworzeniu globalnej nierównowagi płatniczej, $\mathrm{CAB}_{i}$ - wartość salda bilansu obrotów bieżących kraju $i$.

Wspomniane miary globalnej nierównowagi płatniczej są oparte na saldzie bilansu obrotów bieżących, a więc odnoszą się do przepływów (flows). Jednakże w analizie równowagi zewnętrznej krajów przydatny jest także inny wskaźnik, oparty na wielkościach skumulowanych (stocks), a mianowicie międzynarodowa pozycja inwestycyjna. Przedstawia ona zestawienie stanów zagranicznych aktywów i pasywów podmiotów krajowych na koniec danego roku. Różnica pomiędzy wielkością aktywów i pasywów zagranicznych stanowi międzynarodową pozycję inwestycyjną netto i informuje, czy dany kraj jest wierzycielem, czy też dłużnikiem netto w stosunku do zagranicy. W przypadku krajów kreujących globalną nierównowagę międzynarodowa pozycja inwestycyjna kształtuje się podobnie jak saldo bilansu obrotów bieżących, tj. w przypadku krajów deficytowych jest ujemna, a w przypadku krajów nadwyżkowych dodatnia. Oznacza to, że kraje deficytowe są dłużnikami wobec zagranicy, a kraje nadwyżkowe wierzycielami ${ }^{6}$.

Należy podkreślić, że nie każda globalna nierównowaga jest zjawiskiem niekorzystnym. Nierównowagę bilansu obrotów bieżących należy oceniać, każdorazowo biorąc pod uwagę sytuację gospodarczą konkretnego kraju. Przykładowo, w krajach doświadczających szybkiego starzenia się społeczeństwa wskazane będzie gromadzenie oszczędności, z których finansowane będą przyszłe świadczenia emerytalne. W krajach takich nadwyżki bilansu obrotów bieżących są uzasadnione. Natomiast w dynamicznie rozwijających się gospodarkach wschodzacych z młodą populacją uzasadnione będzie utrzymywanie deficytów bilansu obrotów bieżących, zwłaszcza jeśli będą służyły finansowaniu wydatków inwestycyjnych.

Jednakże inaczej jest w sytuacji, gdy nierównowagi bilansu obrotów bieżących są rezultatem zaburzeń wewnątrz gospodarek poszczególnych krajów, które powstają w rezultacie działań w zakresie polityki gospodarczej, w szczególności monetarnej, fiskalnej, handlowej i kursowej (distortive policies) ${ }^{7}$. Tego typu nierównowagi mogą stanowić zagrożenie zarówno dla stabilności finansowej poszczególnych krajów, jak i stabilności całej gospodarki światowej. Dlatego Międzynarodowy Fundusz Walutowy opracował metodologię oceny nierównowag zewnętrznych

${ }^{6}$ L. Mello, P. Padoan, Are Global Imbalances Sustainable?, OECD Economics Department Working Paper No. 795, Organisation for Economic Co-operation and Development, Paris 2010, s. 6.

7 Rebalancing the Global Economy..., s. 88. 
krajów członkowskich. Metodologia External Balance Assessment (EBA) jest podstawą ocen pozycji zewnętrznych poszczególnych gospodarek publikowanych od 2012 r. w External Sector Reports. Ponadto wyniki uzyskane za pomoca modeli EBA stanowia przedmiot konsultacji na podstawie art. IV statutu MFW i są podstawa formułowanych pod adresem krajów członkowskich rekomendacji odnoszących się do przywrócenia równowagi zewnętrznej.

Tabela 1. Oceny pozycji zewnętrznej kraju stosowane w metodologii EBA

\begin{tabular}{|c|c|l|}
\hline $\begin{array}{c}\text { Luka bilansu } \\
\text { obrotów bieżących }\end{array}$ & $\begin{array}{c}\text { Luka realnego } \\
\text { efektywnego kursu } \\
\text { walutowego }\end{array}$ & \multicolumn{1}{|c|}{$\begin{array}{c}\text { Ocena pozycji } \\
\text { zewnętrznej kraju }\end{array}$} \\
\hline$>4 \%$ & $<-20 \%$ & $\ldots$ znacznie silniejsza... \\
\hline$[2 \%, 4 \%]$ & {$[-20 \%,-10 \%]$} & $\ldots$ silniejsza... \\
\hline$[1 \%, 2 \%]$ & {$[-10 \%,-5 \%]$} & ...umiarkowanie silniejsza... \\
\hline$[-1 \%, 1 \%]$ & {$[-5 \%, 5 \%]$} & $\begin{array}{l}\text { Pozycja zewnętrzna jest generalnie zgodna } \\
\text { z fundamentami makroekonomicznymi } \\
\text { i pożądaną polityką ekonomiczną }\end{array}$ \\
\hline$[-2 \%,-1 \%]$ & {$[5 \%, 10 \%]$} & ...umiarkowanie słabsza... \\
\hline$[-4 \%,-2 \%]$ & {$[10 \%, 20 \%]$} & ...słabsza... \\
\hline$<-4 \%$ & $>20 \%$ & ...znacznie słabsza... \\
\hline
\end{tabular}

Źródło: The External Balance Assessment Methodology: 2018 Update, IMF Working Paper No. WP/19/65, International Monetary Fund, Washington, DC 2019.

Kluczowe znaczenie ma zatem określenie benchmarku (normy), który pozwala ocenić, czy pozycja zewnętrzna danego kraju jest zgodna z fundamentami makroekonomicznymi i pożądaną polityką ekonomiczną (consistent with fundamentals and desired policies), czy też występującą nierównowagę można uznać za nadmierną (excessive imbalances). MFW, określając wspomniane normy, posługuje się modelami EBA. Do oceny pozycji zewnętrznej danego kraju stosowane są dwie zmienne: saldo bilansu obrotów bieżących oraz realny efektywny kurs walutowy ${ }^{8}$. W przypadku pierwszej zmiennej różnica pomiędzy wyznaczoną dla danego kraju normą a wartością rzeczywistą stanowi tzw. lukę bilansu obrotów bieżących (current account gap). Dodatnia (ujemna) wartość wspomnianej luki oznacza, że saldo bilansu obrotów bieżących jest zbyt wysokie (niskie) w stosunku do poziomu zgodnego z fundamentami makroekonomicznymi i pożądaną polityką ekonomiczną. W przypadku realnego efektywnego kursu walutowego obliczana jest również luka (REER gap). Dodatnia (ujemna) luka realnego efektywnego kursu walutowego oznacza, że waluta danego

8 The External Balance Assessment Methodology: 2018 Update, IMF Working Paper No. WP/19/65, International Monetary Fund, Washington, DC 2019. 
kraju jest przewartościowana (niedowartościowana). Pozycja zewnętrzna danego kraju, cechującego się nierównowaga, będzie oceniona jako silniejsza (słabsza) niż zgodna z fundamentami makroekonomicznymi i pożądana polityką ekonomiczną, jeśli saldo bilansu obrotów bieżących jest zbyt wysokie (niskie) i/lub waluta krajowa jest niedowartościowana (przewartościowana). W ocenie MFW w $2018 \mathrm{r}$. ok. $40 \%$ całkowitych nierównowag występujących w gospodarce światowej stanowiły nierównowagi nadmierne (excessive imbalances) ${ }^{9}$.

\section{Ewolucja wielkości i struktury globalnej nierównowagi płatniczej}

Obserwacja podstawowego wskaźnika globalnej nierównowagi (oznaczonego w punkcie pierwszym jako GI) wskazuje na szybkie jej narastanie w pierwszej dekadzie XXI wieku i nagłe przerwanie tego trendu wraz z wybuchem globalnego kryzysu finansowego. Wskaźnik GI w 2001 r. wynosił 3\%, a szczytową wartość 5,5\% światowego PKB osiagnął w 2006 r. W latach 2008-2009 globalna nierównowaga skurczyła się o $34 \%$, co w znacznym stopniu wynikało z gwałtownego załamania handlu światowego. Wartość wskaźnika GI spadła w 2009 r. do 3,6\%. Wraz z powolnym ożywieniem w gospodarce światowej po 2009 r. wskaźnik globalnej nierównowagi zaczął ponownie rosnąć, jednak szybko ustabilizował się na poziomie przewyższającym $3 \%{ }^{10}$. Poza stabilizacją wartości globalną nierównowagę płatniczą w okresie pokryzysowym cechuje także trwałość (persistence), co było jej istotną cechą w latach poprzedzających kryzys.

W okresie pokryzysowym nastapiła rekonfiguracja globalnej nierównowagi płatniczej. W szczególności zauważalny jest wzrost udziału gospodarek wysoko rozwiniętych (Advanced Economies - AEs) i spadek udziału gospodarek wschodzących i rozwijających się (Emerging Market and Developing Economies - EMDEs) w kreacji tego zjawiska. W 2007 r. kraje AEs odpowiadały za 69,8\%, a kraje EMDEs za 30,2\% globalnej nierównowagi, podczas gdy w 2018 r. udział krajów AEs wynosił $74 \%$, a krajów EMDEs 26\%. Jednakże znacząco większa skala rekonfiguracji globalnej nierównowagi jest widoczna, gdy porówna się udziały krajów AEs i EMDEs odpowiednio w zagregowanych wartościach deficytów i nadwyżek w gospodarce światowej. W 2007 r. udział krajów AEs w zagregowanych wartościach deficytów wynosił $84 \%$, a w przypadku nadwyżek $54,5 \%$. Następnie w okresie pokryzysowym relacje te uległy znaczącej zmianie i w 2018 r. wynosiły $68,9 \% \mathrm{w}$ przypadku deficytów i 77,7\% w przypadku nadwyżek. Odwrotna tendencja wystąpiła w krajach wschodzących i rozwijających się. W 2007 r. udział krajów EMDEs

9 External Sector Report. The Dynamics of External Adjustment, International Monetary Fund, Washington, DC, July 2019.

10 Obliczenia na podstawie danych World Economic Outlook Database, MFW 2019. 
w zagregowanych wartościach deficytów wynosił 16\%, a w przypadku nadwyżek 45,5\%. W okresie pokryzysowym relacje te istotnie zmieniły się i w $2018 \mathrm{r}$. wynosiły $22,3 \% \mathrm{w}$ przypadku nadwyżek i $31,1 \% \mathrm{w}$ przypadku deficytów. $Z$ analizy przedstawionych danych płyną dwa wnioski. Po pierwsze, udział krajów wysoko rozwiniętych w kreacji globalnej nierównowagi po stronie deficytowej spadł w omawianym okresie o 15,1 p.p., a po stronie nadwyżkowej wzrósł o 23,2 p.p. (analogiczna była wielkość wzrostu udziału gospodarek wschodzących i rozwijających się po stronie deficytowej i spadku po stronie nadwyżkowej) $)^{11}$. Po drugie, znacząco większa rekonfiguracja globalnej nierównowagi płatniczej nastąpiła po stronie nadwyżkowej niż po stronie deficytowej.

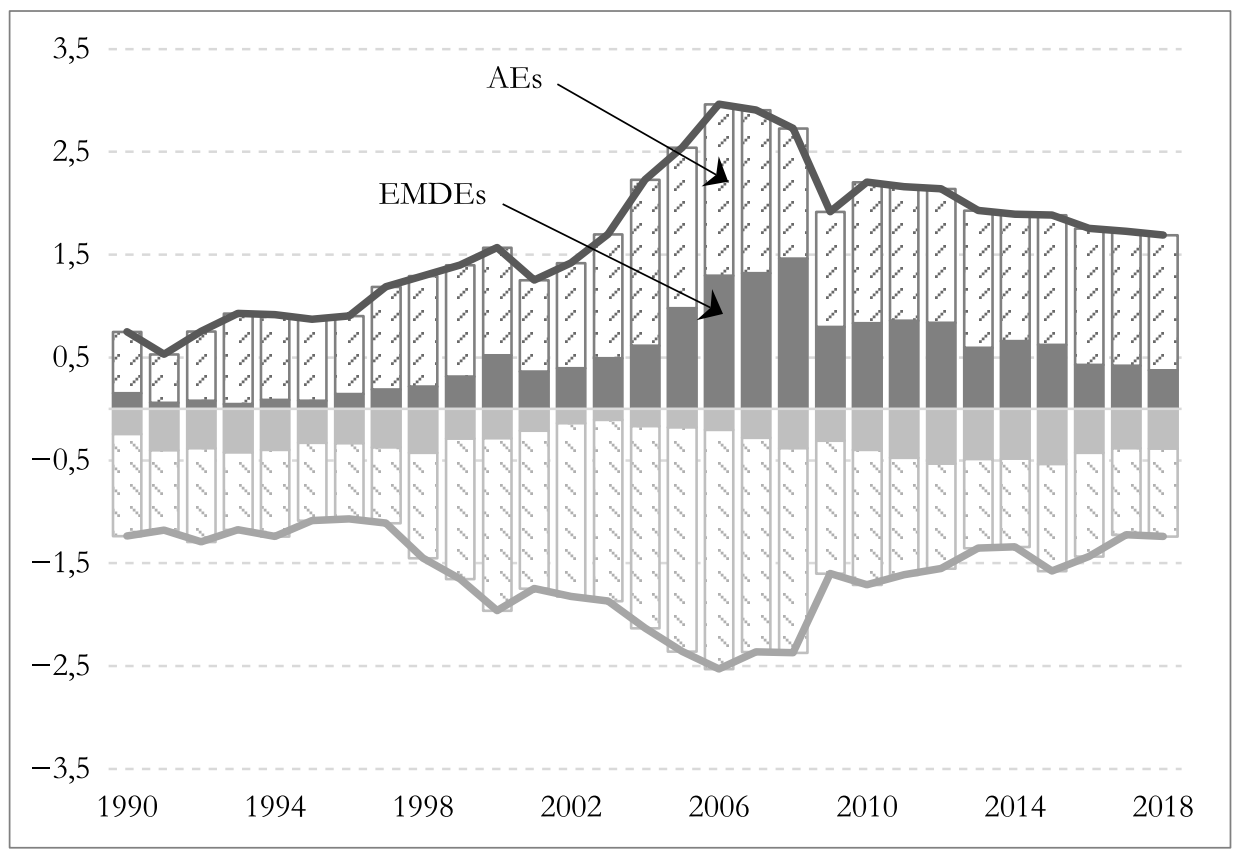

Rys. 1. Nadwyżki i deficyty bilansów obrotów bieżących w gospodarce światowej w latach 1990-2018 (jako \% światowego PKB) ${ }^{12}$

Źródło: Global Imbalances, International Monetary Fund, Washington, DC 2019, s. 4.

11 Obliczenia własne na podstawie danych MFW.

12 Sumy deficytów i nadwyżek powinny z założenia być takie same, tylko posiadać przeciwne znaki. Deficytom jednych państw muszą bowiem odpowiadać nadwyżki innych o takiej samej wielkości. Jednakże różnice w prowadzeniu statystyk bilansu obrotów bieżących w poszczególnych krajach powodują, że wartości te zazwyczaj różnią się, przy czym skala tej różnicy jest nieznaczna. 
Przedstawione dotychczas dane odnosiły się do nierównowagi zewnętrznej mierzonej saldem bilansu obrotów bieżących, a więc przedstawiały flow imbalances. Szczególną cechą charakteryzującą ewolucję globalnej nierównowagi płatniczej w okresie pokryzysowym jest natomiast wzrost nierównowag mierzonych wartością międzynarodowej pozycji inwestycyjnej netto (Net International Investment Position - NIIP), a więc stock imbalances. W 2018 r. globalna międzynarodowa pozycja inwestycyjna netto odpowiadała rekordowo wysokiej relacji $40 \%$ światowego PKB, czyli była ponad czterokrotnie większa niż w 1990 r., kiedy wynosiła 8,3\% światowego PKB. W przypadku tej miary koncentracja nierównowag w gospodarkach wysoko rozwiniętych jest szczególnie widoczna. W 2007 r. skumulowane wartości NIIP krajów wysoko rozwiniętych stanowiły 18,5\% światowego PKB, a w 2018 r. odsetek ten wyniósł aż 30,1\%. Według danych MFW w krajach wschodzących i rozwijających się skumulowane wartości NIIP w 2007 r. stanowiły 8,5\% światowego PKB, a w 2018 r. udział ten wyniósł 9,2\%. Oznacza to, że za przyrost stock imbalances $\mathrm{w}$ okresie pokryzysowym odpowiadały w przeważającej mierze kraje wysoko rozwinięte.

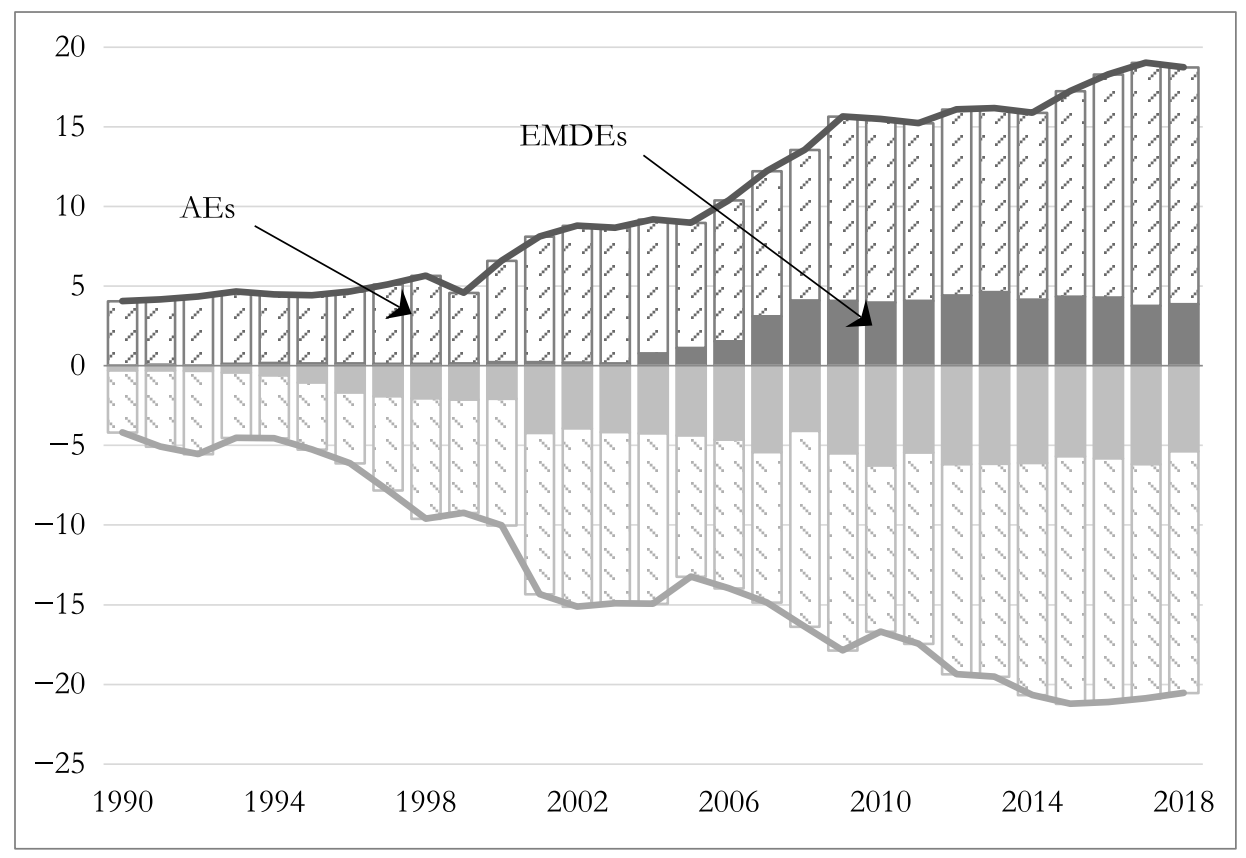

Rys. 2. Międzynarodowe pozycje inwestycyjne netto w gospodarce światowej w latach 1990_ 2018 (jako \% światowego PKB)

Źródło: Global Imbalances, International Monetary Fund, Washington, DC 2019, s. 8. 


\section{Ewolucja determinant globalnej nierównowagi płatniczej}

Źródłem nadmiernej nierównowagi zewnętrznej danego kraju może być zarówno jego własna polityka makroekonomiczna i strukturalna (domestic distortions), jak i polityka gospodarcza innych krajów (foreign distortions). Nierównowagi zewnętrzne poszczególnych krajów są pochodnymi ich nierównowagi wewnętrznej. W przypadku krajów nadwyżkowych wiąże się to z nadmiernymi oszczędnościami w stosunku do inwestycji i konsumpcji. W znacznej części tych krajów głównym źródłem wzrostu gospodarczego jest eksport. Do niedawna sytuacja taka była charakterystyczna zwłaszcza dla gospodarki Chin, dziś natomiast najwyraźniejszymi przykładami sa gospodarki Niemiec i Singapuru. W krajach deficytowych, szczególnie w Stanach Zjednoczonych, oszczędności pozostają znacząco niższe od inwestycji i konsumpcji, natomiast wzrost gospodarczy opiera się w przeważającej mierze na konsumpcji. Tkwiące w prowadzonej polityce makroekonomicznej źródła nadmiernej nierównowagi zewnętrznej mogą być wielorakie. Przykładowo, zbyt restrykcyjna polityka fiskalna doprowadziła do nadmiernych nadwyżek bilansu obrotów bieżacych w Niemczech i Korei. Luźna polityka monetarna poprzez łatwość pozyskania kredytów doprowadziła natomiast do nadmiernych deficytów bilansu obrotów bieżących w Kanadzie i Turcji ${ }^{13}$. Poza politykami składającymi się na politykę makroekonomiczną źródłem nadmiernych nierównowag zewnętrznych może być również polityka strukturalna, w szczególności w odniesieniu do rynku pracy. Utrzymywanie zbyt wielu ograniczeń na tym rynku obniża wzrost produktywności i prowadzi do powstawania deficytów bilansu obrotów bieżących.

W okresie przedkryzysowym jedną z głównych przyczyn globalnej nierównowagi płatniczej była polityka kursu walutowego realizowana przez Chiny. System stałego kursu walutowego sprzyjał rozwojowi wymiany międzynarodowej Państwa Środka, gdyż praktycznie eliminował ryzyko kursu walutowego. Przede wszystkim jednak znaczenie polityki kursu walutowego Chin dla kreacji globalnej nierównowagi wiązało się z utrzymywaniem przez lata niedowartościowania juana poprzez znaczące, systematyczne i jednokierunkowe interwencje Ludowego Banku Chin na rynku walutowym. Polityka ta była więc traktowana jako instrument realizacji proeksportowej strategii wzrostu gospodarczego. Interwencje na rynku walutowym doprowadzily także do bezprecedensowej akumulacji rezerw walutowych przez Chiny ${ }^{14}$.

Najważniejszą zmianą w okresie pokryzysowym było to, że polityka kursu walutowego Chin przestała być przyczyna globalnej nierównowagi płatniczej. Szczególne znaczenie miały w tym przypadku reformy polegające na stopniowym uela-

13 External Sector Report...

14 D. Skopiec, Polityka kursu walutowego Chin jako caynnik globalnej nierównowagi płatniczej, Warszawa 2013. 
stycznianiu reżimu kursowego oraz dopuszczeniu systematycznej aprecjacji juana w stosunku do dolara amerykańskiego. W lipcu 2005 r. Ludowy Bank Chin przeprowadził zasadniczą zmianę systemu kursowego. W miejsce trwającego od $1994 \mathrm{r}$. silnego powiązania juana z dolarem wprowadzono system, w którym chińska waluta oficjalnie została powiązana z koszykiem walut, a poziom kursu w większym stopniu miał odzwierciedlać interakcję popytu i podaży na rynku walutowym ${ }^{15}$. Wspomniana reforma reżimu kursowego doprowadziła do systematycznej realnej aprecjacji juana w stosunku do dolara i znacznego zmniejszenia stopnia niedowartościowania waluty Chin. Najważniejszym efektem systematycznej aprecjacji chińskiej waluty było zmniejszenie stopnia jej niedowartościowania wobec dolara amerykańskiego. Należy podkreślić, że Chiny również stopniowo uelastyczniały system kursu walutowego. Polegało to na poszerzaniu pasma dopuszczalnych wahań kursu juana wokół parytetu. W maju 2007 r. pasmo wahá́ rozszerzono z $\pm 0,3 \%$ do $\pm 0,5 \%$, w kwietniu 2012 r. poszerzono je do $\pm 1 \%$, natomiast w marcu 2014 r. do $\pm 2 \%$. W rezultacie prowadzonej reformy systemu kursowego w latach 2007-2018 waluta Chin uległa realnej skumulowanej aprecjacji w wysokości 36,3\%, co przełożyło się na spadek cenowej konkurencyjności chińskiego eksportu i zmniejszenie nadwyżek bilansu obrotów bieżących tego kraju.

Należy pamiętać, że poza polityką kursową również inne elementy polityki gospodarczej Chin przyczyniały się do powstawania i utrzymywania się globalnej nierównowagi, gdyż prowadziły w sposób często pomijający reguły rynkowe do wzrostu eksportu i narastania nadwyżek bilansu obrotów bieżących. W okresie pokryzysowym Chiny wprowadziły jednak istotne zmiany w polityce gospodarczej ze względu na negatywne skutki proeksportowego, ekstensywnego modelu wzrostu gospodarczego. Mając świadomość, że w dłuższym okresie te negatywne konsekwencje mogą stanowić zagrożenie dla trwałości wzrostu gospodarczego i władzy Komunistycznej Partii Chin, zdecydowano o konieczności przebudowy modelu wzrostu gospodarczego. Przede wszystkim założono, że dywersyfikacja źródeł wzrostu gospodarczego Chin w postaci zmniejszenia roli źródła zewnętrznego (popyt na eksport) i zwiększenia roli źródła wewnętrznego (popyt krajowy) pozwoli na osiagnięcie bardziej zrównoważonego i trwałego wzrostu gospodarczego, a także przyczyni się do ograniczenia nierównowagi wewnętrznej i zewnętrznej Chin ${ }^{16}$.

Dążenie do zmiany modelu wzrostu gospodarczego zostało wyrażone już w Planie Pięcioletnim na lata 2011-2015. Wskazano w nim na konieczność oparcia wzrostu gospodarczego na rynku wewnętrznym. Ponadto plan zakładał wspieranie wewnętrznego popytu oraz sektora usług celem bardziej zrównoważonego wzrostu gospodarczego bazującego na konsumpcji, inwestycjach, eksporcie i usługach. Elementem reform miało być także wspieranie systemu opieki zdrowotnej i edukacji

15 M. Goldstein, N. Lardy, Debating China's Exchange Rate Policy, Washington, DC 2008.

16 Rebalancing the Global Economy..., s. 97-100. 
oraz ochrona środowiska naturalnego ${ }^{17}$. Należy zauważyć, że władzom udało się doprowadzić do istotnych przekształceń modelu gospodarczego, co skutkowało zmniejszeniem dynamiki wzrostu gospodarczego i systematycznym spadkiem nadwyżek bilansu obrotów bieżących. Ponadto w ostatnich latach spadek nadwyżek Chin był też rezultatem poluzowania polityki fiskalnej i kredytowej. Należy podkreślić, że wojna handlowa pomiędzy Stanami Zjednoczonymi a Chinami, której przejawem był wzrost ceł na ok. $40 \%$ wzajemnego importu, nie doprowadziła do zmniejszenia skali globalnej nierównowagi płatniczej. Co prawda, deficyt Stanów Zjednoczonych w handlu z Chinami zmniejszył się, jednakże całkowity deficyt bilansu obrotów bieżących Stanów Zjednoczonych pozostał niezmieniony ${ }^{18}$.

Poza przywróceniem równowagi zewnętrznej Chin główną przyczyną spadku udziału gospodarek wschodzących i rozwijających się w kreacji globalnej nierównowagi płatniczej po stronie nadwyżkowej był spadek cen ropy naftowej po $2013 \mathrm{r}$., który doprowadził do zmniejszenia nadwyżek krajów eksportujących ropę naftowa i ich roli w kreacji globalnej nierównowagi płatniczej.

Natomiast do wzrostu roli krajów EMDEs w kreacji globalnej nierównowagi po stronie deficytowej doprowadziły nowe i szersze możliwości finansowania deficytów budżetowych zadłużeniem zagranicznym. Wśród przyczyn bezprecedensowego wzrostu zadłużenia globalnego po globalnym kryzysie finansowym szczególną rolę odegrały utrzymujące się przez długi czas niskie stopy procentowe. Efektem tego był spadek kosztów pozyskiwania przez rządy kapitału za pomoca instrumentów dłużnych. Ponadto istotną rolę odebrały takie czynniki, jak wzrost roli banków regionalnych (czemu towarzyszył spadek udziału banków globalnych w kredytowaniu EMDEs; ponadto $2 / 3$ kredytów zaciaganych $\mathrm{w}$ bankach regionalnych pochodzi z banków chińskich), wzrost popytu na obligacje nominowane w walutach krajowych, wzrost popytu równoległego sektora bankowego (shadow banking) na instrumenty dłużne krajów EMDEs, a także nadal niski poziom rozwoju instytucjonalnego w tych $\mathrm{krajach}^{19}$.

Do wzrostu udziału gospodarek wysoko rozwiniętych w kreacji globalnej nierównowagi po stronie nadwyżkowej przyczyniła się w szczególności zmiana sytuacji w strefie euro. Poprawa salda bilansu obrotów bieżących i przejście do nadwyżek oscylujących wokół 3\% PKB strefy w latach 2016-2018 wynikały w znacznej mierze $\mathrm{z}$ restrykcyjnej polityki fiskalnej w większości krajów strefy oraz daleko idących reform strukturalnych w zadłużonych gospodarkach peryferyjnych. Istotnym czynnikiem była także skumulowana deprecjacja realnego efektywnego kursu walutowego euro, która w latach 2007-2018 wyniosła 88,7\% i przełożyła się na wzrost cenowej konkurencyjności eksportu krajów strefy.

17 W. Jiabao, Report on the Work of the Government, Fourth Session of the Eleventh National People's Congress, Beijing 5.03.2011.

18 Drivers of Bilateral Trade Balances and the Spillovers from Tariffs [w:] World Economic Outlook, International Monetary Fund, Washington, DC, April 2019.

19 Global Waves of Debt: Causes and Consequences, The World Bank Group, Washington, DC 2020. 


\section{Zmiany w grupach krajów deficytowych i nadwyżkowych}

Przed globalnym kryzysem finansowym grupę krajów deficytowych tworzyły przede wszystkim Stany Zjednoczone oraz większość krajów Unii Europejskiej. Państwa te odnotowały nie tylko deficyty bilansów obrotów bieżących, lecz także ujemne międzynarodowe pozycje inwestycyjne netto. Nierównowagi wewnętrzne w tych krajach, a mianowicie znacząco wyższa konsumpcja od oszczędności, były źródłem ich nierównowagi zewnętrznej.

W okresie pokryzysowym restrykcyjna polityka fiskalna oraz reformy strukturalne realizowane w grupie krajów peryferyjnych strefy euro doprowadziły do eliminacji znaczących deficytów bilansu obrotów bieżących w tych krajach. W porównaniu z 2010 r., w 2018 r. w pierwszej piętnastce krajów posiadających najwyższe deficyty bilansu obrotów bieżących nie było już takich krajów strefy euro, jak Hiszpania, Portugalia, Grecja i Włochy. Istotną rolę w procesie przywracania równowagi zewnętrznej odegrała pomoc finansowa i programy dostosowawcze Międzynarodowego Funduszu Walutowego. Eliminacja znaczących deficytów wspomnianych krajów przyczyniła się do poprawy pozycji zewnętrznej całej strefy euro, która od 2012 r. osiaga nadwyżki bilansu obrotów bieżących.

Tabela 2. Kraje o najwyższych wartościach deficytów bilansu obrotów bieżących w 2010 i $2018 \mathrm{r}$. (mld USD)

\begin{tabular}{|l|c|l|c|}
\hline \multicolumn{2}{|c|}{2010} & \multicolumn{2}{c|}{2018} \\
\hline Stany Zjednoczone & 471 & Stany Zjednoczone & 478 \\
\hline Wielka Brytania & 72 & Wielka Brytania & 109 \\
\hline Włochy & 68 & Indie & 68 \\
\hline Hiszpania & 64 & Kanada & 45 \\
\hline Kanada & 49 & Brazylia & 42 \\
\hline Turcja & 48 & Indonezja & 31 \\
\hline Brazylia & 47 & Australia & 29 \\
\hline Francja & 45 & Argentyna & 27 \\
\hline Indie & 43 & Turcja & 27 \\
\hline Australia & 33 & Meksyk & 22 \\
\hline Grecja & 32 & Pakistan & 16 \\
\hline Portugalia & 22 & Algieria & 15 \\
\hline Polska & 21 & Liban & 15 \\
\hline RPA & 10 & Brazylia & 13 \\
\hline Kolumbia & 9 & Kolumbia & \\
\hline
\end{tabular}

Źródło: Opracowanie własne na podstawie danych World Economic Outlook Database, MFW 2019. 
W okresie pokryzysowym nastąpiło dalsze umocnienie Stanów Zjednoczonych i Wielkiej Brytanii jako dwóch krajów posiadających najwyższe deficyty bilansu obrotów bieżących. Rozmiar deficytów pozostaje znaczny również w relacji do ich PKB. W 2018 r. deficyt bilansu obrotów bieżących stanowił 2,3\% PKB w Stanach Zjednoczonych i 3,9\% PKB w Wielkiej Brytanii. Oba kraje cechuje ponadto ujemna międzynarodowa pozycja inwestycyjna netto. W 2018 r. stanowiła ona 47,4\% PKB w Stanach Zjednoczonych i 6,7\% PKB w Wielkiej Brytanii ${ }^{20}$. Oba państwa odpowiadają nadal w największym stopniu za kreację globalnej nierównowagi po stronie nadwyżkowej. W 2018 r. udział Stanów Zjednoczonych w tworzeniu globalnej nierównowagi wynosił 18,94\%, zaś Wielkiej Brytanii 4,75\% (tab. 3).

Tabela 3. Udział głównych krajów deficytowych w tworzeniu globalnej nierównowagi płatniczej $(\%)$

\begin{tabular}{|l|c|c|c|c|c|c|c|c|c|c|c|c|}
\hline \multicolumn{1}{|c|}{ Kraj } & $\mathbf{2 0 0 7}$ & $\mathbf{2 0 0 8}$ & $\mathbf{2 0 0 9}$ & $\mathbf{2 0 1 0}$ & $\mathbf{2 0 1 1}$ & $\mathbf{2 0 1 2}$ & $\mathbf{2 0 1 3}$ & $\mathbf{2 0 1 4}$ & $\mathbf{2 0 1 5}$ & $\mathbf{2 0 1 6}$ & $\mathbf{2 0 1 7}$ & $\mathbf{2 0 1 8}$ \\
\hline $\begin{array}{l}\text { Stany } \\
\text { Zjednoczone }\end{array}$ & 23,49 & 20,97 & 17,73 & 16,88 & 16,55 & 15,55 & 13,75 & 14,30 & 15,69 & 17,95 & 18,51 & 18,94 \\
\hline $\begin{array}{l}\text { Wielka } \\
\text { Brytania }\end{array}$ & 3,41 & 3,53 & 3,80 & 3,08 & 1,73 & 3,38 & 5,24 & 5,66 & 5,52 & 5,94 & 3,92 & 4,75 \\
\hline Indie & 0,27 & 0,95 & 1,25 & 2,13 & 2,32 & 3,33 & 1,94 & 1,07 & 0,86 & 0,51 & 1,61 & 2,53 \\
\hline Kanada & 0,37 & 0,10 & 1,94 & 2,28 & 1,85 & 2,39 & 2,34 & 1,69 & 2,13 & 2,06 & 1,95 & 1,75 \\
\hline Indonezja & 0,05 & 0,87 & 1,16 & 3,09 & 2,83 & 3,05 & 3,15 & 3,97 & 2,10 & 1,02 & 0,63 & 1,60 \\
\hline Australia & 0,35 & 0,00 & 0,51 & 0,20 & 0,06 & 0,89 & 1,15 & 1,08 & 0,67 & 0,71 & 0,68 & 1,20 \\
\hline Argentyna & 2,12 & 1,60 & 2,33 & 1,75 & 1,65 & 2,35 & 1,89 & 1,70 & 2,19 & 1,72 & 1,51 & 1,14 \\
\hline Turcja & 0,20 & 0,17 & 0,35 & 0,06 & 0,20 & 0,08 & 0,52 & 0,36 & 0,68 & 0,63 & 1,33 & 1,06 \\
\hline Meksyk & 1,22 & 1,21 & 0,54 & 1,75 & 2,76 & 1,75 & 2,51 & 1,71 & 1,24 & 1,39 & 1,99 & 1,04 \\
\hline Pakistan & 0,33 & 0,52 & 0,37 & 0,19 & 0,44 & 0,68 & 1,24 & 0,98 & 1,19 & 1,02 & 0,85 & 0,85 \\
\hline
\end{tabular}

Źródło: Opracowanie własne na podstawie danych World Development Indicators Database, World Bank 2020.

Biorąc pod uwagę metodologię EBA, w 2018 r. do krajów cechujących się nadmiernymi deficytami bilansu obrotów bieżących (excess deficit countries) należały przede wszystkim Stany Zjednoczone, Wielka Brytania, Kanada, Argentyna i Australia $^{21}$. Jak wspomniano, w okresie pokryzysowym udział gospodarek wschodzących i rozwijających się w kreacji globalnej nierównowagi spadł znacząco po stronie nadwyżkowej, a wzrósł po stronie deficytowej. Temu zjawisku towarzyszyło bezprecedensowe narastanie zadłużenia, zwłaszcza zagranicznego, krajów EMDEs. W tej grupie całkowite zadłużenie wzrosło o 54 pp. PKB od 2010 r., osiagając poziom

20 World Economic Outlook Database, MFW 2019.

21 External Sector Report..., s. 15. 


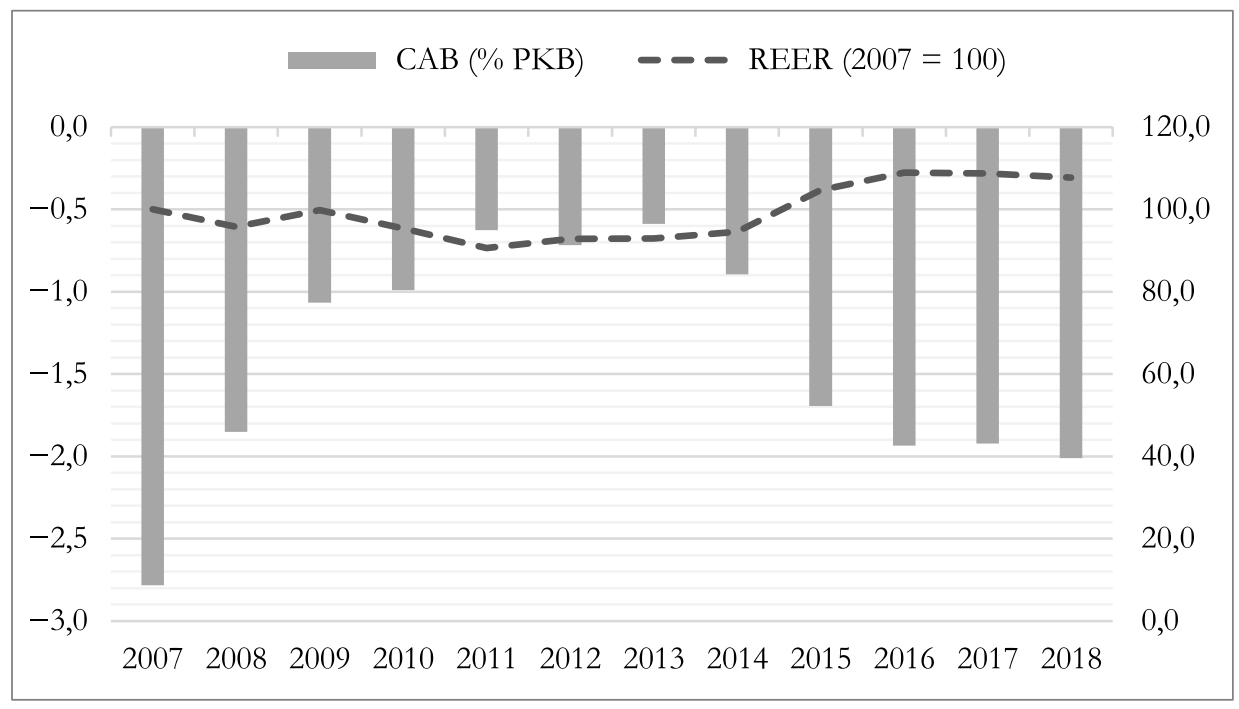

Rys. 3. Saldo bilansu obrotów bieżących (CAB) i realny efektywny kurs walutowy (REER) Stanów Zjednoczonych w latach 2007-2018

Źródło: Opracowanie własne na podstawie danych External Sector Report: The Dynamics of External Adjustment, International Monetary Fund, Washington, DC 2019.

170\% PKB w 2018 r. Poza wzrostem skali i dynamiki zadłużenia zwiększał się również profil jego ryzyka (w odniesieniu do terminów zapadalności, kompozycji walutowej i typu kredytodawcy). Wzrósł udział zadłużenia krótkoterminowego i zagranicznego. Do 2018 r. udział nierezydentów w rynku rządowych instrumentów dłużnych w EMDEs wzrósł do $43 \%$.

Przed globalnym kryzysem finansowym wśród krajów nadwyżkowych dominowały dwie wyraźnie wyodrębnione grupy. Pierwszą z nich były gospodarki wschodzące w Azji Wschodniej. Wzrost roli krajów tego regionu wiązał się przede wszystkim z ich integracją z gospodarką światową oraz szybkim rozwojem opartym na strategii proeksportowej i związanym z tym wzrostem udziału w handlu światowym. Dominującą rolę odgrywały tu przez lata Chiny. Drugą grupa krajów nadwyżkowych były państwa eksportujące ropę naftowa, które osiagały wysokie nadwyżki w związku ze znacznym wzrostem cen tego surowca przed kryzysem ${ }^{23}$.

Najważniejszą cechą charakteryzującą ewolucję grupy krajów nadwyżkowych w okresie pokryzysowym jest przywrócenie równowagi zewnętrznej w Chinach. W okresie poprzedzającym globalny kryzys Państwo Środka miało największy udział w kreacji globalnej nierównowagi po stronie nadwyżkowej. Decydującym

22 Global Waves of Debt...

23 J. Boysen-Hogrefe, K. Gern, N. Jannsen, Will Global Imbalances Decrease or Even Increase? [w:]

The Crisis and Beyond, eds. H. Klodt, H. Lehment, Kiel 2009, s. 111, 112. 
czynnikiem była tutaj akcesja Chin do Światowej Organizacji Handlu w 2001 r. Od tego czasu ich udział w tworzeniu globalnej nierównowagi wzrósł z 1,75\% w 2001 do 11,29\% w 2010 r. ${ }^{24} \mathrm{~W}$ tym czasie Chiny stały się największym światowym eksporterem, wyprzedzając Niemcy w 2009 r.

Załamanie handlu światowego w związku z kryzysem stało się początkiem trendu spadkowego nadwyżek bilansu obrotów bieżących osiąganych przez Chiny. Nadwyżka ta zmniejszyła się z 9,9\% PKB w 2007 do zaledwie 0,4\% PKB w 2018 r. Doprowadził do tego zarówno spadek nadwyżek uzyskiwanych w handlu towarami, jak i systematyczny wzrost deficytu w handlu usługami (spadek od niewielkiej nadwyżki w wysokości 0,1\% PKB w 2007 r. do deficytu w wysokości 2,2\% PKB w 2018 r. $)^{25}$. Istotne znaczenie miał również wzrost importu surowców przez Chiny. Drugim czynnikiem, który świadczy o przywróceniu równowagi zewnętrznej w tym państwie, jest ewolucja realnego efektywnego kursu walutowego juana. W latach 2007-2018 waluta Chin uległa realnej skumulowanej aprecjacji w wysokości 36,3\%. W omawianym okresie udział Chin w kreacji globalnej nierównowagi po stronie nadwyżkowej skurczył się z 11,7\% w 2007 do 1,9\% w 2018 r. (tab. 5).

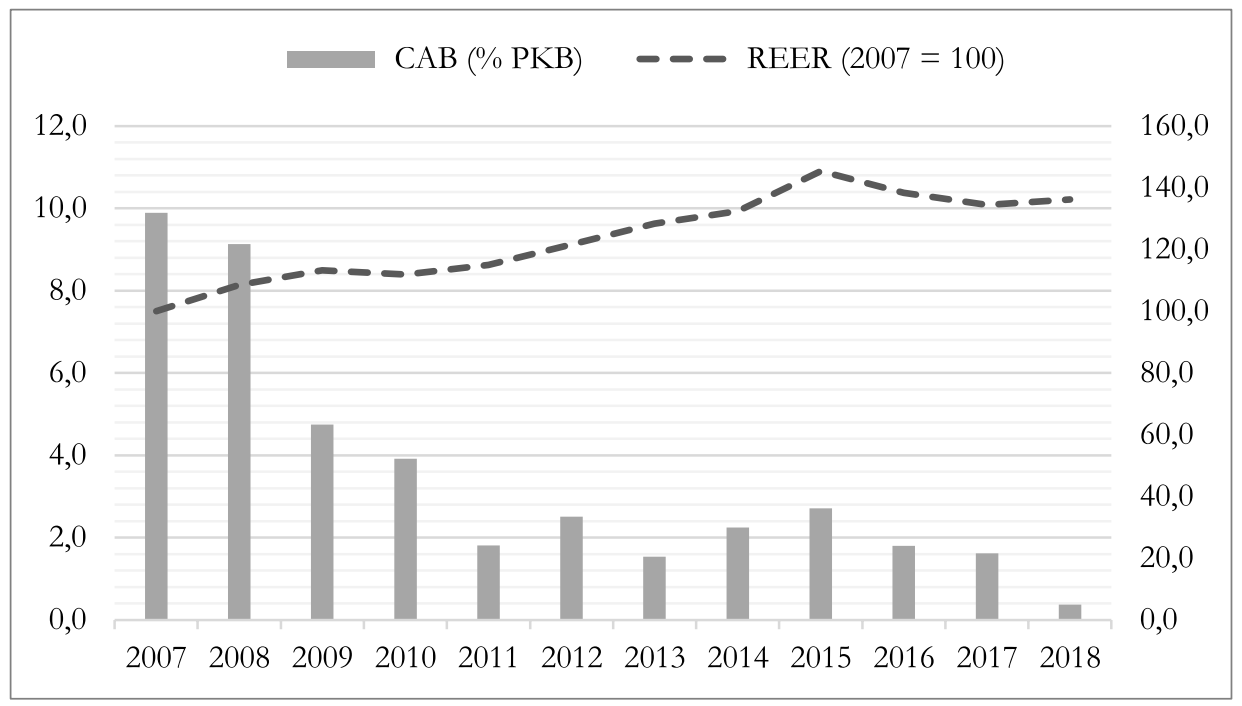

Rys. 4. Saldo bilansu obrotów bieżących (CAB) i realny efektywny kurs walutowy (REER) Chin w latach 2007-2018

Źródło: Opracowanie własne na podstawie danych External Sector Report: The Dynamics of External Adjustment, International Monetary Fund, Washington, DC 2019.

24 Obliczenia na podstawie danych World Economic Outlook Database, MFW 2011.

25 People's Republic of China: Staff Report for the 2019 Article IV Consultation, International Monetary Fund, Washington, DC 2019. 
Drugim poza przywróceniem równowagi zewnętrznej Chin czynnikiem charakteryzującym zmiany w grupie krajów nadwyżkowych w okresie pokryzysowym jest znaczący wzrost nadwyżki bilansu obrotów bieżących Niemiec. W 2018 r. stanowiła ona 7,3\% PKB, natomiast międzynarodowa pozycja inwestycyjna netto Niemiec w relacji do PKB wyniosła $60,6 \%{ }^{26}$. Znacząca nierównowaga zewnętrzna tego kraju stanowi odzwierciedlenie jego nierównowagi wewnętrznej, która przejawia się znacząco wyższym poziomem oszczędności nad inwestycjami. Wśród przyczyn permanentnie wysokich nadwyżek bilansu obrotów bieżących Niemiec należy wskazać w szczególności wolniejszy wzrost płac w stosunku do pozostałych krajów strefy euro, wysokie oszczędności przedsiębiorstw, słaby popyt krajowy i restrykcyjna politykę fiskalną. W pokryzysowej gospodarce światowej Niemcy stały się krajem, który w największym stopniu przyczynia się do kreacji globalnej nierównowagi płatniczej po stronie nadwyżkowej. W 2018 r. udział ten wyniósł 11,2\% (tab. 5).

Tabela 4. Kraje o najwyższych wartościach nadwyżek bilansu obrotów bieżących w 2010 i 2018 r. (mld USD)

\begin{tabular}{|l|c|l|c|}
\hline \multicolumn{2}{|c|}{2010} & \multicolumn{2}{c|}{2018} \\
\hline Chiny & 305 & Niemcy & 291 \\
\hline Japonia & 196 & Japonia & 175 \\
\hline Niemcy & 187 & Rosja & 114 \\
\hline Szwajcaria & 84 & Holandia & 99 \\
\hline Rosja & 71 & Korea Południowa & 76 \\
\hline Arabia Saudyjska & 67 & Arabia Saudyjska & 72 \\
\hline Holandia & 56 & Szwajcaria & 72 \\
\hline Norwegia & 51 & Tajwan & 68 \\
\hline Singapur & 49 & Singapur & 65 \\
\hline Tajwan & 40 & Włochy & 53 \\
\hline Kuwejt & 37 & Chiny & 49 \\
\hline Katar & 32 & Tajlandia & 35 \\
\hline Szwecja & 29 & Norwegia & 35 \\
\hline Korea Południowa & 28 & Irlandia & 34 \\
\hline Malezja & 27 & ZEA & 28 \\
\hline
\end{tabular}

Źródło: Opracowanie własne na podstawie danych World Economic Outlook Database, MFW 2019.

26 Germany: Staff Report for the 2019 Article IV Consultation, International Monetary Fund, Washington, DC 2019. 
Tabela 5. Udział głównych krajów nadwyżkowych w tworzeniu globalnej nierównowagi płatniczej $(\%)$

\begin{tabular}{|l|r|r|r|r|r|r|r|r|r|r|r|r|}
\hline \multicolumn{1}{|c|}{ Kraj } & $\mathbf{2 0 0 7}$ & $\mathbf{2 0 0 8}$ & $\mathbf{2 0 0 9}$ & $\mathbf{2 0 1 0}$ & $\mathbf{2 0 1 1}$ & $\mathbf{2 0 1 2}$ & $\mathbf{2 0 1 3}$ & $\mathbf{2 0 1 4}$ & $\mathbf{2 0 1 5}$ & $\mathbf{2 0 1 6}$ & $\mathbf{2 0 1 7}$ & $\mathbf{2 0 1 8}$ \\
\hline Niemcy & $\mathbf{7 , 7 9}$ & $\mathbf{6 , 5 6}$ & 9,57 & $\mathbf{7 , 6 8}$ & $\mathbf{8 , 6 1}$ & 9,16 & 9,67 & $\mathbf{1 0 , 9 0}$ & $\mathbf{1 1 , 0 9}$ & 12,31 & 12,48 & 11,19 \\
\hline Japonia & 6,99 & 4,37 & 6,93 & 8,64 & $\mathbf{4 , 8 1}$ & 2,19 & 1,83 & 1,42 & 5,25 & 8,26 & 8,49 & 6,74 \\
\hline Rosja & 2,38 & 3,20 & 2,40 & 2,64 & 3,61 & 2,60 & 1,32 & 2,25 & 2,61 & 1,03 & 1,37 & 4,38 \\
\hline Holandia & 1,65 & 1,20 & 2,38 & 2,42 & 3,02 & 3,26 & 3,37 & 2,97 & 1,87 & 2,64 & 3,80 & 3,82 \\
\hline $\begin{array}{l}\text { Korea } \\
\text { Południowa }\end{array}$ & 0,35 & 0,05 & 1,57 & 1,09 & 0,62 & 1,78 & 3,05 & 3,25 & 4,04 & 4,10 & 3,17 & 2,95 \\
\hline Szwajcaria & 1,58 & 0,41 & 1,94 & 3,36 & 2,03 & 2,60 & 3,14 & 2,37 & 2,94 & 2,66 & 1,87 & 2,86 \\
\hline $\begin{array}{l}\text { Arabia } \\
\text { Saudyjska }\end{array}$ & 3,08 & 4,07 & 1,00 & 2,61 & 5,89 & 6,00 & 5,34 & 2,89 & 2,18 & 1,00 & 0,44 & 2,72 \\
\hline Singapur & 1,62 & 0,90 & 1,51 & 2,15 & 2,30 & 1,90 & 1,90 & 2,21 & 2,04 & 2,33 & 2,33 & 2,51 \\
\hline Włochy & 1,01 & 2,06 & 1,92 & 2,86 & 2,54 & 0,27 & 0,84 & 1,57 & 0,98 & 2,03 & 2,25 & 2,08 \\
\hline Chiny & 11,67 & 12,94 & 11,58 & 9,31 & 5,05 & 7,85 & 5,84 & 9,24 & 11,70 & 8,47 & 8,21 & 1,89 \\
\hline
\end{tabular}

Źródło: Opracowanie własne na podstawie danych World Development Indicators Database, World Bank 2020.

Nadwyżkową stronę globalnej nierównowagi płatniczej w okresie pokryzysowym cechuje w dalszym ciagu bardzo wysoka pozycja Japonii. W 2018 r. nadwyżka rachunku bieżącego Japonii stanowiła 3,5\% PKB. Jednakże w tym przypadku znaczącym źródłem nadwyżek jest nie tyle bilans handlowy, ile bilans dochodów pierwotnych. Podobnie jak w przypadku Niemiec, nierównowaga zewnętrzna Japonii stanowi pochodna jej nierównowagi wewnętrznej, której głównym źródłem pozostają bardzo wysokie oszczędności przedsiębiorstw. Międzynarodowa pozycja inwestycyjna Japonii pozostaje niezmiennie dodatnia i w 2018 r. stanowiła $61 \% \mathrm{PKB}^{27}$.

Niezmiennie wysoką pozycję wśród krajów nadwyżkowych zajmuje Holandia, odnotowując nadwyżki bilansu obrotów bieżących permanentnie od 1981 r. Kraj ten cechuje ponadto bardzo wysoka nadwyżka rachunku bieżącego do PKB, która w 2018 r. wynosiła aż 10,8\%. Ponadto bardzo silnie dodatnia pozostaje międzynarodowa pozycja inwestycyjna netto Holandii - 66,7\% PKB w 2018 r. ${ }^{28}$

Biorąc pod uwagę metodologię EBA, w 2018 r. do krajów cechujących się nadmiernymi nadwyżkami bilansu obrotów bieżących (excess surplus countries) należały przede wszystkim Niemcy, Holandia, Singapur, Korea Południowa i Tajlandia. Po-

${ }^{27}$ Japan: Staff Report for the 2019 Article IV Consultation, International Monetary Fund, Washington, DC 2019.

28 The Kingdom of Netherlands: Staff Report for the 2019 Article IV Consultation, International Monetary Fund, Washington, DC 2019. 
mimo znaczącej nadwyżki bilansu obrotów bieżących, Japonia nie została zaliczona przez MFW do krajów z nadmierną nierównowagą zewnętrzną ${ }^{29}$.

\section{Ryzyka związane z globalną nierównowagą płatniczą}

Ryzyka i koszty związane z globalną nierównowagą płatniczą należy rozpatrywać odrębnie dla poszczególnych krajów posiadających nadmierne nierównowagi zewnętrzne (zarówno deficyty, jak i nadwyżki) oraz dla całej gospodarki światowej. O skali wspomnianych ryzyk i kosztów w pokryzysowej gospodarce światowej decyduje fakt, że w ocenie MFW w 2018 r. ok. 40\% całkowitych nierównowag występujących w gospodarce światowej stanowiły nierównowagi nadmierne (excessive imbalances).

Państwa deficytowe ponoszą znaczne koszty obsługi swojego zadłużenia zagranicznego, co staje się szczególnie dotkliwe, gdy dług jest spłacany poprzez zaciaganie nowego. Wysokie koszty obsługi długu mogą stanowić barierę rozwojową dla danego państwa. W szczególności dotyczy to sytuacji, kiedy ciężar związany z obsługa długu stanowi ograniczenie dla finansowania edukacji, ochrony zdrowia $\mathrm{i}$ inwestycji infrastrukturalnych ${ }^{30}$.

Nadmierne deficyty bilansu obrotów bieżących nie stanowią większego problemu w przypadku krajów będących emitentami kluczowych walut międzynarodowych. Zagrożenia w przypadku nadmiernych deficytów są natomiast bardzo poważne w krajach EMDEs, które finansowały deficyty zaciąganiem długu zagranicznego. W ich przypadku wzrost awersji do ryzyka i premii za ryzyko wskutek wystapienia negatywnego szoku doprowadzi do wzrostu kosztów obsługi zadłużenia i stworzy problemy związane z refinansowaniem. Kraje EMDEs są narażone w znacznym stopniu na zjawiska sudden stop i gwałtowny odpływ kapitału. Należy podkreślić, że w ostatnich latach nastąpił wzrost profilu ryzyka charakteryzujący zadłużenie tych krajów, a mianowicie wzrost udziału pożyczkodawców niebędących członkami Klubu Paryskiego i pożyczkodawców prywatnych. Ponadto następuje intensyfikacja ryzyk zewnętrznych, czyli charakteryzujących gospodarkę światowa, w szczególności spowolnienie tempa wzrostu światowego PKB, odwrót od multilateralizmu, zaostrzenie sporów w handlu światowym, napięcia geopolityczne, zmiany klimatu i ich negatywne ekonomiczne konsekwencje (zwłaszcza dla krajów narażonych na częste katastrofy naturalne) $)^{31}$.

\footnotetext{
29 External Sector Report..., s. 15.

30 IMF Annual Report 2019: Our Connected World, International Monetary Fund, Washington, DC 2019, s. 12.

31 Trade and Development Report 2019, United Nations Conference on Trade and Development, Geneva 2019.
} 
Państwa notujące chroniczne deficyty bilansów obrotów bieżących borykają się z kryzysami w sektorach eksportowych (relokalizacja produkcji do nadwyżkowych krajów wschodzących i rozwijających się) oraz wysoką stopą bezrobocia, co rodzi tendencje protekcjonistyczne, których najlepszym przykładem jest eskalacja sporów handlowych pomiędzy Stanami Zjednoczonymi i Chinami. Rosnący protekcjonizm stwarza nie tylko ryzyko odwrotu od liberalizacji handlu światowego, ale może prowadzić do przedłużającej się wojny handlowej ${ }^{32}$. Tego rodzaju zjawiska moga stać się również elementem szerszej tendencji do deglobalizacji.

Kraje nadwyżkowe ponoszą także koszty znaczącej i chronicznej nierównowagi zewnętrznej. Jednym z nich jest koszt akumulacji znacznych rezerw walutowych i zarządzania nimi. Rezerwy te są utrzymywane w ogromnej mierze w amerykańskich rządowych papierach dłużnych, oferujących stosunkowo niską stopę zwrotu w stosunku do wielu innych inwestycji, wobec których stanowią koszt alternatyw$n y^{33}$. Akumulacja rezerw walutowych prowadzi do zwiększonej ekspozycji na ryzyko kursu walutowego, gdyż w przypadku aprecjacji waluty krajowej i deprecjacji waluty obcej wartość tych rezerw wyrażona w walucie krajowej spada ${ }^{34}$. Interwencje na rynku walutowym mające na celu wpływanie na poziom kursu walutowego powodują też problemy z kontrolą podaży pieniądza, w związku z czym banki centralne prowadzą operacje sterylizacyjne. Ponieważ kierunek interwencji krajów nadwyżkowych na rynku walutowym jest zazwyczaj niezmienny, tj. polegają one na zakupie walut obcych za walutę krajową celem zapobieżenia aprecjacji waluty krajowej, to w ramach sterylizacji bank centralny emituje bony, od których musi jednak płacić odsetki, będące de facto kosztem sterylizacji.

Koszty globalnej nierównowagi należy rozpatrywać także w odniesieniu do gospodarki światowej jako całości. Są to koszty systemowe (systemic costs) w postaci permanentnego zagrożenia dla stabilności makroekonomicznej i finansowej w gospodarce światowej w średnim i długim okresie. Szczególnym ryzykiem związanym z globalną nierównowaga jest w tym przypadku jej trwałość (persistence). Uważa się, że im dłużej nierównowaga ta utrzymuje się, tym większe ryzyko jej korekty w drodze kryzysu (disorderly unwinding) i związanej z tym globalnej recesji ${ }^{35}$. Należy pamiętać, że globalna nierównowaga płatnicza jest uważana za jeden z głównych czynników odpowiedzialnych za globalny kryzys finansowy lat 2008-2009. Wynikało to z napływu kapitału do Stanów Zjednoczonych, którego źródłem były państwa nadwyżkowe, osiągające znaczne wpływy z eksportu. Doprowadziło to wskutek

32 A. Aslud, M. Dabrowski, Challenges of Globalization: Imbalances and Growth, Peterson Institute for International Economics, Washington 2008, s. 129-131.

33 C. Adams, D. Park, Causes and Consequences of Global Imbalances: Perspective from Developing Asia, „Asian Development Review” 2009, vol. 26, no. 1, s. 40.

34 F. Warnock, How Might a Disorderly Resolution of Global Imbalances Affect Global Wealth?, Working Paper No. WP/06/170, International Monetary Fund, Washington 2006, s. 3, 4.

35 Rebalancing the Global Economy..., s. 39-41. 
nadmiaru płynności do spadku amerykańskich stóp procentowych, a także globalnej stopy procentowej ${ }^{36}$. Należy jednak podkreślić, że czynnikiem zmniejszającym ryzyko systemowe w pokryzysowej gospodarce światowej jest umocniona globalna sieć bezpieczeństwa finansowego (Global Financial Safety Net - GFSN), którą tworzą rezerwy dewizowe poszczególnych krajów, bilateralne porozumienia o swapach walutowych zawierane pomiędzy bankami centralnymi, regionalne porozumienia finansowe (Regional Financing Arrangements - RFA) oraz zasoby finansowe $\mathrm{MFW}^{37}$.

\section{Podsumowanie}

Globalny kryzys finansowy spowodował gwałtowne zmniejszenie się skali globalnej nierównowagi płatniczej, w szczególności wskutek załamania handlu światowego. Wraz z powolnym ożywieniem w gospodarce światowej po 2009 r. globalna nierównowaga zaczęła ponownie rosnąć, jednak szybko uległa stabilizacji. Ponadto w okresie pokryzysowym, podobnie jak w latach poprzedzajacych kryzys, globalna nierównowagę cechuje też trwałość.

W okresie pokryzysowym nastapiła rekonfiguracja globalnej nierównowagi płatniczej. Zauważalny jest przede wszystkim wzrost udziału gospodarek wysoko rozwiniętych oraz spadek udziału gospodarek wschodzacych i rozwijających się w kreacji tego zjawiska. Wzrosły też nierównowagi mierzone wartością międzynarodowej pozycji inwestycyjnej netto. Przeprowadzona analiza wykazała, że za przyrost stock imbalances $\mathrm{w}$ okresie pokryzysowym odpowiadały w przeważającej mierze kraje wysoko rozwinięte. Nastapiło dalsze umocnienie Stanów Zjednoczonych i Wielkiej Brytanii jako dwóch krajów posiadających najwyższe deficyty bilansu obrotów bieżących. Co szczególne, ewolucję grupy krajów nadwyżkowych w okresie pokryzysowym cechuje przywrócenie równowagi zewnętrznej w Chinach, ale należy też w tym kontekście wskazać na znaczący wzrost nadwyżek bilansu obrotów bieżących Niemiec.

\footnotetext{
36 M. Obstfeld, K. Rogoff, Global Imbalances and the Financial Crisis: Products of Common Causes, Berkley 2009.

37 IMF Annual Report 2018: Building a Shared Future, International Monetary Fund, Washington, DC 2018, s. 6, 7.
} 


\section{SUMMARY}

\section{EVOLUTION OF GLOBAL IMBALANCES IN THE POST-CRISIS WORLD ECONOMY}

Global imbalances, i.e. external positions of systemically important economies that reflect distortions or entail risks for the global economy, remain one of the key characteristics of the contemporary world economy. After narrowing sharply in the aftermath of the global financial crisis, overall current account surpluses and deficits stabilized at around 3 percent of global GDP. However, according to the International Monetary Fund's External Sector Report about 35-45 percent of overall current account surpluses and deficits were deemed excessive in 2018. Moreover, the post-crisis period has been characterized by external rebalancing of the Chinese economy, the rise of EMDEs in overall deficits as well as persistency of deficits in the US and the UK. Following the global financial crisis, global imbalances have also been increasingly concentrated in advanced economies. 